\title{
Perspective of Chinese soft power resources energy enterprises "going out" strategy Path
}

\author{
Shi Hong 11, Qi LinKai 2 \\ 1,2Business School, Hohai University, Nanjing, China, 211100
}

\begin{abstract}
Energy resources in our country enterprises "going out" strategy, theory and practice, based on the analysis of current situation, noting that in today's complex changes in the international environment, the hard power alone cannot achieve the "going out" strategy objectives, are required to pass increase its soft power to enhance the "going out" competitiveness and for country-led and energy resources under the guidance of foreign investment plan, put forward by means of soft power factors to build a "going out" strategy to achieve pathway countermeasures.
\end{abstract}

Key words: soft power,energy resources, foreign investment,strategy of "going out"

\section{Proposing views concerned current situation}

The strategy of "going out" is in depth analysis of international and domestic political and economic situation, based on the enable our enterprises to actively participate in international competition, full plays to the "two markets and two resources", and further enhance the international competitiveness to force a major strategic decision, and is a essential requirement of economic globalization, but also it is the inevitable choice for China to promote strategic adjustment of economic structure. The Report at 16th Party

Since 1997, China made full use of the "going out" strategy; foreign investment of China's energy resources has entered a new era. Especially in the 21st century, with China's economic strength and increasing demand for mineral resources, China's foreign investment of energy resources began to expand rapidly. While only 22 million barrels 10 years ago. According to some international consulting companies (such as securities, Lyon, France) estimated that in 2004 foreign investment projects in energy resources accounted for the total $1 / 2$ strength (53\%) of China's foreign investment. It further indicates that foreign investment in energy resources has become the most important part of China's "going out" strategy.

However, from theoretical research perspective the research on foreign direct investment of enterprise, the home is little scholars special on resources energy, specifically for this particular type of status of China's foreign investment in-depth exposition of the system, even though there are a few addresses of foreign investment in energy resources, articles, only from the investment motive, characteristics of factor endowments, and investment types .

On the other hand, from the management practice perspective, the development of energy resources-based industries has been a national focus on the support of foreign direct investment, in a long time, exemplified among Japan and America, the global resource and energy strategy has been implemented as the significant combination within the national whole plan. However, as China's foreign direct investment is growing, especially in the extend and scale on foreign investment for energy resources, as well as the global investment scope over the world, the Western countries have been surrounded by the extremely panic for the China's rise on 
economy, military and politics, adding up the foment of popularized China Threat Theory and the whole unprecedented awakening on politics, the "Go Out" strategy, which will be applied among our energy and resource enterprises, won't be work if just depending on the strength level on national economy, military and technology. In a word, we have no other choice but to share the universal political culture with the rest of people, to build the higher level of corporation framework based on public anticipation and boarder democratic values, and to extend the national soft power, which all targeting on eliminating the energy-owned countries' worries about the rise of China over the economy, military and politics and to facilitate to achieve win-win and corporation and common development.

\section{2. the theoretical study of the status and its limitations}

The term "going out" strategy refers to elements from the product, capital to technology, from personnel to manage a comprehensive initiative to enter the international market, give full play to the "two markets", "two kinds of resources" effect, it including exports of goods and services, labor export, international finance, international economic and technological cooperation and exchanges, foreign investment and other aspects of multinational enterprises. Narrow sense of "going out" strategy mainly refers to the enterprises through foreign direct investment as the main way to enter the international market, international competition and cooperation, so as to improve their international competitiveness, and promote their rapid, sustained and coordinated development.

Because the term "going out" strategy voluminous content, combined with China on exports of goods and services and other aspects of theoretical research and practical experience which has been very rich and mature, so this paper select "going out" strategy of narrow sense as the main research the content.

The majority of our scholars elaborated on foreign investment mainly in foreign direct investment from Europe and the theory of macro-level theoretical analysis. The theory on foreign direct investment in Europe and developed countries are seven kinds, namely, Alzheimer's and co-founded his mentor Kindleberger's theory of monopoly, oligopoly Knickerbocker's theory, Harvard University economics professor Vernon's product life cycle theory, from the Heckscher and Ohlin's "factor endowment" theory of regional advantages theory, internalization theory of Buckley's, the British scholar Dunning's eclectic theory of international production, the Japanese scholar Kojima's marginal industrial expansion theory. Each of the theories is from different sides of the interpretation of cross-border investments.

China scholars Xing Houyuan (2008) According to Deng Ning's "stage theory of foreign investment", combined with the Swiss bank announced the provincial units of China in 2007 per capita gross national product (GNP) data, the analysis pointed out: the internationalization of China's economy has been generally in the third phase, that is, foreign investment absorbing and external investment have a significant increase in stage. ${ }^{1}$ Scholar Lu Tong (1998), through the interpretation of the international mainstream popular theory of foreign investment in the developing countries, and the traditional theory of multinational corporations - "advantage on the premise" development as "out of the development on the edge." 2 Jiang Xiaojuan (2006, 2008) perspective from factor endowments and considered that China should actively "bringing shortage of natural resources, to improve the matching elements', by expanding and opening up the introduction of elements of the shortage of energy resources, which in particular, elements, to improve total factor productivity and maintain a strong competitive edge. ${ }^{3}$ Wang 
Zhile (2004), pointed out China's enterprises to develop energy resources can exchange for foreign investment and market share, fit the conclusions of DengNing's which to carry out the motivation on foreign investment enterprises in developing countries.Pei Changhong (2008) based on different investment purposes, made our country's foreign investment into four types, , and one of the most important types is "base Resource search type".Lu Jinyong, Yan Shiqiang (2005), summarized the nine kind models of the foreign direct investment in China's business, one of the national strategy-led investment model referring to China's energy resources to foreign investment. ${ }^{4}$

From international trade theory based on the macroscopic level, the development of the economy of our mineral resources such energy security is inadequate, requires a large number of imported from abroad. Foreign investment can stabilize the supply of energy resources and reduce the number of trust in international trade as a series of risk, thus providing security for the development of the economy stable. From industrial organization theory based on the microeconomic level, our country's energy resources enterprises to actively carry out foreign investment, is not conducive to their full competition in the market more competitive, China's energy resources, acts of foreign investment enterprises completely fit the current global academic theories on the main cross-border investment.

However, few scholars are in-depth and systematic to exposition of the status of domestic energy resources, specifically for this particular type of foreign investment, even if a small number of articles of the foreign investment in energy resources discussed only from the investment motive, characteristics of factor endowments, and investment types and models, etc. And the reality is, with all the oil and gas and minerals and some metals as a national strategy resources and energy and resources of all countries to china in energy resources of the scale of foreign investment increases may be the core interests of the state and national security threat and the worries and panic, the extent of our influence and has limited resources of energy sources of foreign investment, In this case, the idea of going to change the view was also needs to be concerned only with hard measure of and to promote, develop and demonstrate by soft power, through the country's foreign international relations, state and ideology and culture, the country to review all human society should show major responsibility for the soft power in to our resources of energy enterprises "going global" strategy, the real topics of theoretical research is an inevitable choice.

\section{3. realities and its resistance of our national resources energy enterprises to "going out"}

In 2009, China has become the country of the Middle East's largest oil importer, but also surpassed the U.S. as the largest exporter to the region's countries. The main objective of China now is to maintain economic and trade in the Middle East and the Gulf region with Saudi Arabia, Iran and Libya and other oil-producing countries, in particularly, to ensure that oil and gas and other energy resources. ${ }^{5}$

Chinese consortium of five companies (led by the CITIC Group, comprising Taiyuan Iron and Steel Group Co., Ltd, Baosteel Group, Anshan Iron and Steel Group and Beijing Shougang Co., Ltd.) will cost \$ 1.95 billion in cash to buy the world's largest manufacturer of niobium - - 15\% stake of Brazilian Metallurgy and Mining Company (CBMM) in the company's total global supply of niobium than $80 \%$ of the total. China's annual steelmaking capacity has been increased to about 700 million tons, which is the world's largest importer of niobium. Last year, China's state-owned East China Nonferrous Metals Geological Survey of 
Australia won the global metals and mining company's controlling stake, which has a niobium mine in Africa.The Chinese consortium to enter the Brazilian mining acts highlights the growing tension in the context of supply of iron and steel manufacturers to ensure that the resources will start to compete.

These are just one or two examples of the outcome of major initiatives of China's implementation of "going out" strategy. In recent decades, China has undergone enormous changes; as the second largest economy over the world, China has not won any compliment, which indeed should be deserved in terms of its achievements on economy; on the contrary, as the surging of "China Threat Tone" spread over the world with the rise of China itself, some neighboring countries and Westerns with serious prejudice both felt anxious and restless on the China's behaviors of supplanting the U.S. to sit on the thrown of the world king. Rooted in the Western worries on the China's further orientation and subsequent series of on its unwillingness to stand on one line, some a sense of distrust exacerbated these Westerns' suspects to impel them to prevent even through two-face strategy, thus leading to the formation of suppressing and counterbalancing China."China threat theory" has become a fact of checking and containing China's rise instrument of public opinion and excuses, which is the interest to promote China's soft power. Through the dissemination of their cultural identity to promote the purpose of soft power because culture is the foundation of the china's behavior. Confucius Institute in the promotion and other similar programs, China's interests and that the interests of many Western countries had found a meeting point, in addition to cultural goodwill, the Western countries have also seen the exposure to employment opportunities. Their pragmatic attitude which will become all hope of getting the other side of understanding between the both Chinese and western, are the most important adhere elixir.

\section{4. "going out" strategy of China's energy enterprises based on soft power resources}

\subsection{The meaning of soft power}

Under the background of the world peace and development become the two major themes, soft power as part of comprehensive national strength has highlighted the increasingly important position. The concept soft power was first proposed by American scholars, former Assistant Secretary of Defense Joseph Nye in 1990. Joseph Nye said: "Soft power is by attracting others rather than forcing them to achieve the goal you want to achieve the ability to influence others, if the power is to achieve what you want the ability to achieve the purpose, then there are three ways you can do to this: by threatening (or stick), through inducements (or carrots), or by attracting and mutual choice - that is soft power."

In recent years, domestic scholars have some of their own discussions about soft power, Zuo Xuejin, Liu Zunyi(2004) considered that: "Soft power is a ability of dominated by a moral to win friends and influence others, which include fair treatment of all countries, no abuse of power (including the hard power), note restraining actions. "6

Zhan Dexiong (2004) proposed that "appeal to the political system, values of the appeal, the appeal of culture, diplomacy, persuasion, and the leaders and the national image of charm and affinity", which was in describing the form of soft power and features .

It can be considered that soft power is relative to GDP, defense forces and other terms of hard power, and is also a country's culture, value, social systems which affected the factors of their development potential and international appeal. 


\subsection{International requirements and needs of soft power}

Soft power since it is the influence of national culture reflected in international relations, we must consider the outside world needs and the requirements to China, combined with their capacity and conditions, beyond the capacity and terms of commitment and action will only harm the prestige. Overall, the world hoped that China would used more and more of soft power and enhanced it. Combed the world demands for China's soft power are the following points: First, developing countries are interested in China's development models and want to study and learn from them. Second, the world hoped that China is a health" checks and balances "in the international system. Third, the international community want that China could made more responsibility to international affairs and contribute more to reflect the wisdom of China's innovative ideas, programs, mechanisms and institutions.

\section{Affecting the factors of the use of soft power to build "going out" strategy realization}

It is still in its infancy for China's soft power building, in response to the situation changes and requirements of today's "going out" strategy, the guidance of "going out" strategy under the government-led energy resources is imperative to do:

4.3.1Adjust the concept and improve the understanding and awareness of soft power, building a core cultural value system.

As the conference of western tradition of geopolitics and the impact of power politics, the century of humiliation left a deep imprint to the Chinese history, so the Chinese can be said for the tireless pursuit of hard power, and not easy to recognize the necessity and effectiveness of soft power. In fact, Western countries dominated the modern international system in the process of formation, it is sufficient to put hard power and soft power effectively together. Thus, the U.S. adopted a strategy of international cooperation. Made China to become a truly great country, it is necessary to enhance its hard power, but also constantly to increase its soft power, fundamentally speaking, it is to strengthen the system construction of China's cultural values, and using the most concise, clear language of outward declaration gradually to get more people to the world's recognition and acceptance.

4.3.2Emancipate the mind; strengthen the research on the ethnic and religious issues, propose the new strategies and policies which meet the new situation requires.

After the Cold War, globalization has reached a new level; nationalism has entered a new stage. Nationalism is a reflection of social forces, in a deeper and more fundamental level, it is better than any sense on the surface form of role and cannot be ignored in more radical forms to play.

Since early 2011, Middle East and North Africa (MENA) countries had made large-scale protests. Regime change in Egypt, Tunisia and Libya into civil war, Yemen, Syria and other countries were continuing conflict in the streets. Investment in the global oil industry in the territory of China and Africa and some Middle Eastern countries has been considered high-risk areas. China's dependence on Middle East and North Africa's oil is very prominent. Therefore, it is necessary to properly handle the relations with these high-risk investors through soft power.

4.3.3Enhance Transmission of the soft power, in particularly, improve the promotion of non-governmental organizations and communication of mass media.

Under the conditions of globalization, the role of mass media has reached unprecedented proportions. As the powerful Western media, with its language and technical advantages of the global dominance, so it has priority on many 
issues. Since China having undergone some disharmonious foreign relations during the past year resulted by the hard power game played on the field of economy, military and politics, it has been making an effort to re-delineate its new national image in the way of cultivating the culture and humanity, such as founding the Confucius Institutes around the world, and displaying the national image film in the Times Square, thus aiming to reduce the international suspecting so as to retch up public appeals and to retrieve the long lost voice on international affairs which had been totally dominated by the West. All of these struggles have consisted of strategic missions involving national interests.

Another important way is to spread non-governmental organizations to strengthen international exchanges. Compared with developed countries, China's non-governmental organizations forces is weak and still in its infancy, so that foreign generally accepted that in the international arena cannot see Chinese non-governmental organizations in the figure, which is a blind spot in China's soft power. Currently, the priority must be to support and assist non-governmental organizations in the establishment of more non-governmental organizations, which based on encouraging them onto the international stage, boldly actively participate in international dialogue, "off the official "and taking "folk" are the next direction of the Chinese soft power and cultural external communication efforts to.

4.3.4Improve the status of soft power, focus on the development of soft power, improve the efficiency of foreign strategy.

In today's theme, usually it appears common and intensified with small friction, and a trade war, information warfare, technology, warfare, so that traditional forms of direct confrontation is transformed into competition of soft power. Therefore, China's foreign strategy is going to follow changes in the external environment and make appropriate adjustments and changes, which cannot stick to their ideological enemies and other factors too, and also it should turn to the development of soft power, and pay more attention to the role of media and public, so that all factors would avoid disadvantages.

4.3.5 Focus on diplomatic skills to show the diplomacy charm of soft power.

At present, foreign cultural exchanges plays an important part of diplomacy, which is increasingly becoming an important pillar of China's foreign relations. However, with China increasingly important on the world stage position the Chinese cultural exchange potential is not fully realized. At the same time, we should bear in mind the teachings of Comrade Deng Xiaoping: keeping a low profile, good humbleness, never take the lead, which must be foreign policy that followed under the new situation. In addition, the main line of China's foreign strategy should be corporation. therefore, the new diplomacy based on all fronts show greater cooperation in the framework will be to demonstrate the charm of soft power diplomacy.

\section{References}

[1] Xing Yuan .Thick speed up "going out" pace, enhance the ability of using the external resources $[\mathrm{J}]$. Chinese foreign investment, 2008, (6)

[2] Lu Tong. WTO and internationalization of Chinese enterprises[J]. Economic Management Publishing House, 2007

[3] Jiang Xiaojuan .Retrospect and Prospect of China opening up for three decades [J].Chinese Social Science, 2008, (6)

[4] Lu Jinyong, Yan Shiqiang. Analysis and comparison of Chinese enterprises overseas investment $[\mathrm{J}]$ model international economics of co-operation, 2005, (3)

[5] The Wall Street Journal (network) ,2011 -9-5

[6] Zuo XueJin, Liu Zunyi, China's strategic choice to increase its soft power [J]. Reference News 2004-08-19 (15) 